\title{
Existence of Visum Et Repertum on the Occurrence of Persecution as Evidence of Work Termination*
}

\author{
Asri Wijayanti, ${ }^{1}$ Satria Unggul Wicaksana Prakasa, ${ }^{2}$ Achmad Hariri, ${ }^{3}$ \\ Agus Supriyo, ${ }^{4}$ Basuki Babussalam ${ }^{5}$ \\ Universitas Muhammadiyah Surabaya, Indonesia \\ doi $10.15408 /$ jch.v9i3.22868
}

\begin{abstract}
Employment relationships may end due to abuse by workers. The existence of abuse must be medically proven. This research aimed to analyze the existence of a visum et repertum for the occurrence of abuse that can be used as evidence in termination of employment. This legal research was normative with a statutory approach. The results showed that persecution was a criminal act. There was no requirement for a judge's decision in the District Court which already had permanent legal force for the occurrence of persecution as a condition for the validity of the layoff as if the visum et repertum was no longer needed. It was enough that the acts of abuse committed by workers were regulated in the Employment Agreement, Company Regulation or Collective Labor Agreement, then the persecution as a form of an urgent violation can be used as a valid reason for the termination of employment (Article 81 number 37 of the Job Creation Law jo. Article 151 / 3 Manpower Law jo. article 52/2 Government Regulation 35/2021. The researchers' efforts to review labor regulations related to urgent violations in the Indonesian manpower system are a form of evaluation of the weaknesses of the Job Creation Law and its implementing regulations can be able to assist legislators to develop and enforce laws that protect certain vulnerable groups namely workers in applying the principle of presumption of innocence.
\end{abstract}

Keywords: Forensics; Persecution; Termination.

\footnotetext{
* Received: May 16, 2021, revised: June 23, 2021, accepted: December 22, 2021, Published: December 23, 2021.

${ }^{1}$ Asri Wijayanti is a lecturer in The Faculty of Law, Universitas Muhammadiyah Surabaya, Indonesia, ORCID ID: http://orcid.org/0000-0001-6542-2958

2 Satria Unggul Wicaksana Prakasa is a Lecturer in The Faculty of Law, Universitas Muhammadiyah Surabaya

${ }^{3}$ Achmad Hariri is a Lecturer in The Faculty of Law, Universitas Muhammadiyah Surabaya

${ }^{4}$ Agus Supriyo is a Lecturer in The Faculty of Law, Universitas Muhammadiyah Surabaya

${ }^{5}$ Basuki Babussalam is a Lecturer in The Faculty of Law, Universitas Muhammadiyah Surabaya. Corresponding author: asri.wijayanti@fh.um-surabaya.ac.id
} 


\title{
Eksistensi Visum Et Repertum Atas Terjadinya Penganiayaan Sebagai Alat Bukti Pemutusan Hubungan Kerja
}

\begin{abstract}
Abstrak
Hubungan kerja dapat berakhir karena adanya penganiayaan yang dilakukan oleh pekerja. Adanya penganiayaan harus dibuktikan secara medis. Penelitian ini bertujuan untuk menganalisis adanya visum et repertum atas terjadinya penganiayaan yang dapat digunakan sebagai alat bukti dalam pemutusan hubungan kerja. Penelitian hukum ini bersifat normatif dengan pendekatan perundang-undangan. Hasil penelitian menunjukkan bahwa penganiayaan adalah perbuatan pidana. Tidak adanya keharusan putusan hakim di Pengadilan Negeri yang sudah memiliki kekuatan hukum tetap atas terjadinya penganiyaan sebagai syarat keabsahan PHK seolah mengakibatkan visum et repertum tidak dibutuhkan lagi. Cukup perbuatan penganiayaan yang dilakukan oleh pekerja diatur dalam Perjanjian Kerja, Peraturan Perusahaan atau Perjanjian Kerja Bersama, maka penganiayaan sebagai wujud telah terjadi pelanggaran yang bersifat mendesak dapat digunakan sebagai alasan keabsahan pemutusan hubungan Kerja (Pasal 81 angka 37 UU Cipta Kerja jo. Pasal 151 /3 UU Ketenagakerjaan jo.Pasal 52/2 Peraturan Pemerintah 35/2021. Upaya penulis untuk mereview peraturan perburuhan terkait pelanggaran yang bersifat mendesak dalam sistim ketenagakerjaan Indonesia merupakan bentuk evaluasi atas adanyan kelemahan UU Cipta Kerja dan Peraturan pelaksananya, akan dapat membantu legislator untuk mengembangkan dan menegakkan hukum yang melindungi kelompok rentan tertentu yaitu pekerja dalam menerapkan asas praduga tak bersalah.
\end{abstract}

Kata Kunci: Forensik; Penganiayaan; Pemutusan Hubungan Kerja

\section{Наличие Visum Et Repertum в случае преследования как доказательство прекращения работы}

\begin{abstract}
Абстрактный
Трудовые отношения могут прекратиться из-за жестокого обращения со стороны работников. Наличие жестокого обращения должно быть доказано с медицинской точки зрения. Это исследование было направлено на анализ наличия visum et repertum в случаях злоупотреблений, которые могут использоваться в качестве доказательства при увольнении. Это правовое исследование было нормативным с законодательным подходом. Результаты показали, что преследование было уголовным преступлением. В районном суде не требовалось вынесения решения судьей, которое уже имело постоянную юридическую силу в связи с преследованием в качестве условия действительности увольнения, как если бы в visum et repertum больше не было необходимости. Достаточно того, чтобы акты жестокого обращения, совершенные работниками, регулировались трудовым договором, регламентом компании или коллективным трудовым договором, тогда преследование как форма неотложного нарушения может быть использовано в качестве уважительной причины для увольнения (статья 81 № 37 Закона о создании рабочих мест, ст. 151/3 Закона о рабочей силе, ст. 52/2 Постановление правительства 35/2021. Усилия исследователей по пересмотру трудового законодательства, касающегося неотложных нарушений в индонезийской системе кадровых ресурсов, являются формой оценки Слабые стороны Закона о создании рабочих мест и его подзаконных актов могут помочь законодателям в разработке и обеспечении соблюдения законов, которые защищают определенные уязвимые группы, а именно работников, в применении принципа презумпции невиновности.
\end{abstract}

Ключевые слова: судебная экспертиза, преследование, прекращение действия 


\section{A. INTRODUCTION}

Every human being always needs income to fulfil his daily needs. One way to earn an income is to work for other people (entrepreneurs or employers). The employment relationship is a legal relationship between a worker and an entrepreneur based on an employment agreement (Kaufman et al. 2019). An employment agreement is an agreement made by workers and employers that have elements of orders, work, and wages (Adanhounme and Levesque 2019).

A working relationship is certainly expected to take place well (Zhang et al. 2020). The continuity of an employment relationship depends on the good faith (Lippmann 2017) of the legal subject who carries out the employment relationship (Fortunati 2018). The employment relationship can end or be terminated due to the will of the employer, the will of the worker, a court decision/decision or by law (Ye, Wang, and Liu 2015). Termination of employment may end at the will of the employer or worker, and may occur because the worker has abused his co-workers or employers in the work environment (Allen 2016).

Persecution is categorized as a criminal act and is regulated in the Articles of the Criminal Code/KUHP. An act is said to be a crime, it must meet certain conditions. The requirements for a criminal act must meet formal, material, subjective and objective elements. Persecution is also divided into levels, namely ordinary persecution, mild persecution, severe persecution, planned persecution, and quality persecution.

\section{B. METHOD}

The research aimed to analyze the existence of visum et repertum on the occurrence of abuse by workers to their co-workers or to employers. The existence of visum et repertum had decreased because there was no obligation to wait for a judge's decision who had been permanently inkracht van gewisdje for abuse which was a form of serious error committed by workers. This legal research (Nalle 2015) was normative (Deryabina 2018) with a statutory approach (Maxwell 2013) and deductive logic (Himma and Bix 2017).

\section{RESULTS AND DISCUSSION}

The results showed that the existence of visum et repertum as evidence for the occurrence of abuse as a reason for termination of employment was 
weakened. The discussion-based is on problems related to the existence of visum et repertum as evidence for the occurrence of persecution as a reason for termination of employment.

Persecution is a criminal act/strafbaar feit that is prohibited by law is detrimental to society (Sonhaji 2019). Persecution from a criminal law perspective based on the provisions of Article 170, 351-358 of the Criminal Code. An act is said to be a criminal act/straftbaar feit that must fulfil formal, material, subjective and objective elements (Mueller-Smith 2016).

The formal element is the existence of a human act whose act is prohibited by a rule of law. The prohibition is accompanied by threats or sanctions in the form of certain crimes and the prohibition is violated by humans. The material element of an unlawful act is that the act must be against the law (Ferrajoli 2011). It means that it must be truly felt by the community as an act should not or should not be suitable to do.

The objective element is an element that is outside of the perpetrator of the crime. Consists of human actions that cause the legal consequences, elements against the law and other elements that determine the nature of the crime, aggravating elements are not criminal. It also the other elements that determine criminal acts. Subjective elements are elements that must be present in the perpetrator of a crime consisting of intentional/dolus, negligence/culpa, intention/voornemen, intention, pre-planning/met voorbedachte rade, feelings of fear/vrees (Doshi-Velez et al. 2017).

Persecution is a deliberate act that results in feelings of pain, injury and feelings of displeasure. There is ill-treatment with torture, suppression of the persecuted. Qualifications of persecution are divided into levels, namely ordinary persecution (causing illness or being unable to carry out a position or work or having a mental disorder for a maximum of four weeks, mild persecution (not causing pain or being unable to do the job/job), severe persecution, planned persecution, and quality persecution. The one who can determine the level or degree of abuse is the doctor through the results of the medical examination as outlined in the form of visum et repertum. (Rizka et al. 2020)

The term visum et repertum is the singular form of visa et reperta contained in Stbl. 1937 No. 350. The term visum et repertum is contained in the Decree of the Minister of Justice No. M.04.UM.01.06 of 1983, namely the results of the judicial medical examination in written form, referred to as visum et repertum. The visum et repertum is a written report made by a doctor who has 
taken an oath about what he saw and found in an examination of the evidence to the examined people who died or were injured were mourned for a crime for a judicial examination. The contents of the visum et repertum consist of introduction, news, conclusion and closing. The introduction contains the identity of the doctor, the applicant for the post-mortem et repertum, the time and place for the post-mortem et repertum. The reports contain everything that is seen and found in the examination of evidence examined by a doctor. The conclusion contains the essence of the results of the examination accompanied by the opinion of the doctor in accordance with his knowledge and experience. It also describes a causal relationship between the condition of the body being examined and its consequences. The closing contains a statement of visum et repertum made under oath. Visum et repertum can be used as evidence in examining criminal cases of persecution by judges in district courts.

Visum et repertum is very necessary as evidence of a criminal act of persecution. It is necessary to have a visum et repertum which is given at the same time for mild maltreatment that does not require hospitalization. A temporary visum et repertum is given temporarily, to explain the condition of the person who was asked for a visum et repertum when the doctor was first examined. Therefore, they still need a further visum et repertum in order to explain the condition of the person who was asked for a visum et repertum at the last time they left the hospital. Visum et repertum continued, given when the person can leave the hospital because it has recovered.

Visum et repertum related to abuse contains a description that describes the condition of the wound, divided into three degrees of injury. First degree injuries (class $\mathrm{C}$ injuries) are injuries that do not require further treatment for the victim. In the case of first-degree injuries, the victim of a crime only requires an examination of his condition and from the results of a forensic medical examination that he does not require further treatment in a hospital. The conclusion of the first-degree wound is that the victim is not hindered in carrying out his position/work/activity. The conclusion showed that the first-degree injury in the visum et repertum, in the context of criminal law, relates to the crime of minor maltreatment as stipulated in Article 352 of the Criminal Code.

Second-degree injuries (class B), namely injuries that require temporary treatment of the victim of a crime. In this case the victim after being observed requires further treatment in the hospital. The conclusion given for the seconddegree injury is an injury that causes the temporary obstruction of the position/job/activity. The conclusion of the second degree wound in the visum et repertum in the context of criminal law is categorized as a criminal act of 
persecution (ordinary) as stipulated in Article 351 paragraph (1) of the Criminal Code.

Third-degree injuries (class A), namely injuries that result in serious injuries. Therefore, they are hindered in carrying out their positions/jobs/activities. With regard to serious injuries, Article 90 of the Criminal Code stipulates, that serious injuries to the body are: a disease or wound that cannot be expected to recover completely, or an injury that can pose a danger of death; continues to be incapable of performing a position or job; no longer has any of the five senses; hood (rompong), paralysis, change of mind (reason) for more than four weeks; killing a child from the mother's womb. Qualification of third-degree injuries from the results of forensic medical examinations, in the context of criminal law according to the Criminal Code, is qualified as severe abuse which is regulated.

The substance of abuse as a reason for termination of employment can be analysed based on the analysis of legal subjects and legal objects. The analysis of the legal subject of persecution is divided into two points of view, namely the perpetrator and the victim. Perpetrators of abuse in this research were limited to workers. Victims of abuse are divided into two legal subjects, namely co-workers of the perpetrators or entrepreneurs.

Persecution from the perspective of labour law, is an act of abuse committed by workers to their co-workers or to employers in the work environment. The existence of acts of abuse committed by workers to their coworkers or to employers in the work environment can initially be the reason for the termination of employment because the worker has made a serious mistake.

Legal subjects in employment relations consist of workers and employers. After researching the existence of criminal acts of persecution in the work relationship. Then it must be determined who committed the crime of persecution, the worker or the entrepreneur? The occurrence of fraud by employers which can be used as a reason for workers to apply for layoffs. Persecution perpetrated by workers against employers can be used as an excuse for employers to terminate their employment because they are deemed to have committed a major or serious mistake.

The termination of employment was caused by a serious mistake, namely the occurrence of abuse by workers against employers. This is determined by the judge at the industrial relations court. In fact, it must not be based on a decision that has permanent legal force (inkracht van gewisjde) from a judge in a district court. Likewise, termination of employment due to a worker's request for a 
complaint that the employer has committed acts of ill-treatment against workers does not have to be based on an inkracht van gewisjde decision from a judge in a district court.

The research of the legal object, in this case, is the occurrence of abuse during the implementation of the employment relationship. When doing work, there is an incident where one of the legal subjects commits a criminal act of persecution against another legal subject. The review of the persecution is based on the fulfilment of the elements of the crime of persecution. The legal content of the provisions of Article 170, Article 351 to Article 358 of the Criminal Code is prohibited. The occurrence of persecution is an act that results in serious injury, death, damage to health. Harassment occurs if it causes feelings of discomfort (suffering), pain or injury. The occurrence of persecution that does not cause illness or an obstacle to work, if it is carried out by the employer to the worker. The sentence is between 5 and 12 years.

The occurrence of persecution by workers against employers can be used as an excuse for employers to terminate their employment because they are considered to have committed a major or serious mistake. The legal consequence of being terminated due to a grave error or serious error is that the worker receives a one-time service award and only compensation money, no severance pays for layoffs due to this serious or grave error.

The occurrence of abuse by workers or employers in an employment relationship must be medically proven in the form of a visum et repertum. Evidence of serious wrongdoing is alternative, namely being caught red-handed or confessions from workers or incident reports supported by at least two witnesses. The rights of workers from this termination of employment are to receive compensation and separation money (Article 158 paragraph (1) letter e jo. Paragraphs (2), (3) and (4) of Law 13/2003).

The three conditions stipulated in Article 158 paragraph (2) of Law 13/2003 must be cumulative, not alternative. The point is that all the conditions stipulated in Article 158 paragraph (2) of Law 13/2003 must exist, the absence of any of the three conditions makes the employer's/laborer's decision that the worker has committed a serious mistake cannot be accepted.

The first condition which states that the worker/labourer has been caught red-handed means that the worker can be proven based on preliminary evidence that he has committed one of the acts stipulated in Article 158 paragraph (1) of Law no. 13 of 2003. There is sufficient preliminary evidence to suggest that the worker has committed a grave error. 
The second requirement is that there is an acknowledgment from the worker/labourer concerned that he or she has committed the alleged act based on initial evidence at the time of his arrest. The acknowledgment of the worker or labourer can be made in oral or written form. In order to guarantee legal certainty, it is better if the acknowledgment of the worker/labourer concerned is made in written form, even better if it is the worker himself (in the sense that it is not made by personnel as is the case in practice). Of course, the making of a statement acknowledging having committed one of the acts included in the criteria for serious wrongdoing must be made with self-awareness, not under coercion, pressure, or deception from the entrepreneur/employer or from the personnel. The point should not be made on the basis of a lie.

The third condition is the existence of other evidence in the form of an incident report made by the competent authority in the company concerned and supported by at least two witnesses. This third condition is basically a continuation of the fulfilment of the first and second conditions. The third condition essentially strengthens the first and second terms.

This is different from the formulation of the provisions of article 158 paragraph 2 which can be interpreted only to determine the three conditions as alternative conditions and not as cumulative conditions (underlined from the author). It is said by interpretation that it shows as an alternative requirement because between article 158 paragraph (2) b and article 158 paragraph (2) c of Law no. 13 of 2003 mentions the word or not and. The use of words and with words or in the context of legal language brings different results. The editorial should be article 158 paragraph (2) of Law no. 13 of 2003 is written "and". The evidence for serious errors should be cumulative which is stated by the word "AND" not alternative which is stated by the word "or". It can lead to potential arbitrariness of entrepreneurs.

The provisions of Article 158 of Law 13/2003 have been declared to have no binding legal force by the Decision of the Constitutional Court Number 012/PUU$1 / 2003$ dated October 28, 2004. The consideration is that the provisions of Article 158 paragraph (1) and paragraph (2) violate the principle of presumption of innocence or the presumption of innocence. Before someone is found guilty by the panel of judges committing a crime, it must be assumed that the person concerned is not guilty. Article 158 paragraph (1) and paragraph (2) also contradicts Article 27 paragraph (1) of the 1945 Constitution, because there is legal discrimination. It is stated that all citizens have the same position in law and government and are obligated to uphold the law and the government with no exceptions. Serious error is a criminal act qualification, but the procedure uses 
civil law procedures, namely filing a lawsuit to the Industrial Relations Court. Not a mechanism for criminal law procedures.

The validity of the Constitutional Court's decision has created a debate regarding its authority. The authority to examine laws against the 1945 Constitution. The decision of the Constitutional Court is final, meaning that the decision of the Constitutional Court immediately acquires permanent legal force from the moment it is pronounced and there are no legal remedies that can be taken. The final nature of the decision of the Constitutional Court in this Law includes the final and binding legal force. (Article 10 paragraph (1) of Law 24/2003 in conjunction with Law 8/2011 concerning the Constitutional Court).

The decision of the Constitutional Court is a type of statutory regulation. Follow-up on the decision of the Constitutional Court is carried out by the DPR or the President (Article 8 paragraph (1) in conjunction with Article 10 paragraph (1) letter $d$ in conjunction with paragraph (2) of Law 12/2011 concerning the establishment of legislation. Unfortunately, the follow-up to the decision of the Constitutional Court Number 012/PUU-1/2003 dated October 28, 2004, which states that the provisions of Article 158 of Law 13/2003 do not have binding legal force, followed up by Circular Letter of the Minister of Manpower and Transmigration Number SE-13/MEN/SJ-HK/ I/2005, which states that if an entrepreneur wants to lay off a worker because the worker has committed a serious mistake, there must be a criminal judge's decision with permanent legal force first. Therefore, the guilt must be proven first through the criminal justice mechanism.

Since November 1, 2020, the provisions of Article 158 of Law 13/2003 have been abolished by Article 81 number 47 of Law 11/2020 on Job Creation. On February 2, 2021, Government Regulation Number 35/2021 has been issued concerning Work Agreements for Certain Time, Outsourcing, Working Time and Rest Time and Termination of Employment. Employers can lay off workers for reasons of workers committing urgent violations as regulated in work agreements, company regulations or collective labour agreements. The rights received by workers are compensation for entitlements and separation pay, the amount of which is regulated in a work agreement, company regulations or collective labour agreement. Compensation for entitlements consists of annual leave that has not been taken or has not yet fallen, the cost of returning the worker and his family to the place where the worker is accepted to work and other matters stipulated in the work agreement, company regulations or collective labour agreement. (Article 52 paragraph (2) in conjunction with Article 40 paragraph (4) Government Regulation Number 35/2021). 
Legal remedies that can be taken for the occurrence of persecution as a reason for termination of employment are informal or formal. Informal legal remedies can be taken by workers who experience violence for the first time through a complaint mechanism to their immediate supervisor, either individually or represented by a trade union, and can be continued by making a report to the local Manpower Office.

If you go through a formal channel that carries out the procedure for reporting a crime, by contacting by telephone to the Police call centre 110 or coming directly to the nearest police station at the Integrated Police Service Centre, to make a police report. After the investigation order is issued, a notification letter for the start of the investigation is issued which is sent to the public prosecutor (Articles 3, 13, 14 of the Regulation of the National Police Chief No. 6/2019 concerning Criminal Investigation).

\section{CONCLUSION}

The existence of Visum et Repertum regarding the occurrence of persecution as evidence in termination of employment in Indonesia was currently weak. It was supposed to determine the validity of the termination of employment due to an urgent worker violation that must be based on the decision of the judge in the District Court which already has permanent legal force. Mistreatment by workers in an employment relationship must be medically proven in the form of a visum et repertum. There was no requirement for a judge's decision in the District Court which already has permanent legal force for the occurrence of persecution as a condition for the validity of the layoff as if the visum et repertum is no longer needed. It is enough that the acts of abuse committed by workers are regulated in the Employment Agreement, Company Regulation or Collective Labour Agreement, then the persecution as a form of an urgent violation can be used as a valid reason for the termination of employment (Article 81 number 37 of the Job Creation Law in conjunction with Article 151 / 3 Manpower Law in conjunction with Article 52/2 of Government Regulation $35 / 2021$.

\section{REFERENCES}

Adanhounme, Armel Brice, and Christian Levesque. 2019. "Collective Bargaining in a Context of Employment Flexibilization in Two Plants in Quebec." Relations Industrielles-Industrial Relations. 
https://doi.org/10.7202/1059463ar.

Allen, Emma R. 2016. "Analysis of Trends and Challenges in the Indonesian Labor Market." Asian Development Bank (ADB) Paper on Indonesia.

Deryabina, E. M. 2018. European Law: Theory and Metodology of Cognition.

European Law: Theory and Metodology of Cognition.

https://doi.org/10.31085/9785392292219-2019-288.

Doshi-Velez, Finale, Mason Kortz, Ryan Budish, Christopher Bavitz, Samuel J. Gershman, David O'Brien, Stuart Shieber, Jim Waldo, David Weinberger, and Alexandra Wood. 2017. "Accountability of AI Under the Law: The Role of Explanation." SSRN Electronic Journal. https://doi.org/10.2139/ssrn.3064761.

Ferrajoli, Luigi. 2011. "The Normative Paradigm of Constitutional Democracy." Res Publica. https://doi.org/10.1007/s11158-011-9169-8.

Fortunati, Leopoldina. 2018. "Immaterial Labor." In The Blackwell Encyclopedia of Sociology. https://doi.org/10.1002/9781405165518.wbeos1128.

Himma, Kenneth Einar, and Brian Bix. 2017. Law and Morality. Law and Morality. https://doi.org/10.4324/9781315092003.

Kaufman, Bruce E., Michael Barry, Rafael Gomez, and Adrian Wilkinson. 2019.

"Evaluating the State of the Employment Relationship: A Balanced

Scorecard Approach Built on Mackenzie King's Model of an Industrial

Relations System." Relations Industrielles / Industrial Relations.

https://doi.org/10.7202/1056973ar.

Lippmann, Walter. 2017. The Good Society. The Good Society.

https://doi.org/10.4324/9781315132273.

Maxwell, Joseph A. 2013. “Conceptual Framework: What Do You Think Is

Going On?" In Qualitative Research Design: An Interactive Approach. https://doi.org/10.1007/978-3-8349-6169-3_3.

Mueller-Smith, M. 2016. “The Criminal and Labor Market Impacts of Incarceration." American Economic Review.

Nalle, Victor Imanuel W. 2015. “The Relevance Of Socio-Legal Studies In Legal Science." Mimbar Hukum - Fakultas Hukum Universitas Gadjah Mada. https://doi.org/10.22146/jmh.15905.

Rizka, Rizka, Wafda Vivid Izziyana, Arief Budiono, Heru Santoso Wahito Nugroho, Sofyan Wimbo Agung Pradnyawan, and Rika Maya Sari. 2020. 
"Visum et Repertum and Forensic Examination of a Rape Case as a Sexual Crime towards an Indonesian Migrant Worker in Taiwan." Indian Journal of Forensic Medicine and Toxicology 14, no. 2: 2538-42.

https://doi.org/10.37506/ijfmt.v14i2.3496.

Sonhaji, Sonhaji. 2019. "Analisis Yuridis Pemutusan Hubungan Kerja Akibat Kesalahan Berat Pekerja." Administrative Law and Governance Journal. https://doi.org/10.14710/alj.v2i1.60-78.

Ye, Bin, Yan Wang, and Ling Liu. 2015. "Crowd Trust: A Context-Aware Trust Model for Worker Selection in Crowdsourcing Environments." In Proceedings - 2015 IEEE International Conference on Web Services, ICWS 2015. https://doi.org/10.1109/ICWS.2015.26.

Zhang, Stephen X., Yifei Wang, Andreas Rauch, and Feng Wei. 2020.

"Unprecedented Disruption of Lives and Work: Health, Distress and Life Satisfaction of Working Adults in China One Month into the COVID-19 Outbreak." Psychiatry Research. https://doi.org/10.1016/j.psychres.2020.112958. 